\title{
PENGEMBANGAN INDUSTRI KREATIF PIGURA KALIGRAFI MENUJU PASAR GLOBAL
}

\author{
Zuliyati \\ Fakultas Ekonomi, Universitas Muria Kudus \\ Email: zuliyatiyati@yahoo.co.id
}

\begin{abstract}
ABSTRAK
Potensi industri kecil yang produktif adalah industri kecil yang kreatif, yaitu industri yang menitik beratkan pada kreativitas dan keinovasian. Salah sata UMKM yang mempunyai peranan besar dalam industri kreatif dan perlu dikembangkan dalam rangka memacu ekspor dan menghadapi pasar global adalah UMKM yang mengandalkan keahlian tangan (hand made), seperti kerajinan perhiasan, ukiran kayu dan termasuk juga Kerajinan Pigura Kaligrafi. Tujuan dari kegiatan ini adalah (I) memacu pertumbuhan ekspor produk Pigura Kaligrafi Indonesia melalui pertumbuhan pasar yang kompetitif, (2) meningkatkan pengembangan Pengrajin Pigura Kaligrafi dalam merebut peluang ekspor melalui peningkatan kualitas produk dan pemasaran Pigura Kaligrafi. Metode yang digunakan adalah Bintek (Bimbingan Teknologi), pendampingan serta penguatan dalam proses produksi. Melalui metode tersebut proses produksi akan menjadi efektif dan efisien, sehingga menghasilkan produk berkualitas . Hasil dari kegiatan yaitu peningkatan nilai aset dan pendapatan Pengrajin Pigura Kaligrafi, peningkatan kuantitas dan kualitas Pigura Kaligrafi yang dipasarkan, peningkatan pemasaran produk dan proses produksi semakin efektif dan efisien.
\end{abstract}

Kata Kunci : Ekspor, Kaligrafi, Kualitas, Pigura, UMKM

\begin{abstract}
The productive potential of small industries is creative industries, the creative industries that focuses on creativity and inovation. One of SMEs that have a major role in the creative industries and should be developed in order to exports and global market is SMEs that rely on the expertise (hand made), such as crafts jewelry, wood carvings and including Frames Craft Calligraphy. The purpose of this activity is to (I) stimulate the growth of exports Frames Calligraphy Indonesia through the growth of a competitive market, (2) enhance the development of Custom Frames Calligraphy in seizing the export opportunities by improving the quality of products and marketing Frames Calligraphy. The method used is Bintek (Guidance Technology), assistance and reinforcement in the production process. Through this method the production process will be effective and efficient, so as to produce quality products. Results of activities, namely the increase in the value of assets and income Craftsmen Frames Calligraphy, increasing the quantity and quality of marketed Calligraphy Frames, increase the marketing of products and production processes more effective and efficient.
\end{abstract}

Keywords: Export, Calligraphy, Quality, Frames, SMEs 


\section{PENDAHULUAN}

Potensi industri kecil yang produktif adalah industri kreatif yang menitik beratkan pada kreatifitas dan keinovasian yang utamanya bergerak dibidang souvenir/handycraft. UMKM yang mempunyai peranan besar dalam ekspor adalah UMKM yang mengandalkan keahlian tangan (hand made), seperti kerajinan perhiasan, ukiran kayu dan termasuk juga produk Kerajinan Pigura Kaligrafi. Karakteristik tersebut merupakan keunggulan kompetitif dan komparatif UMKM, di mana lebih banyak mengandalkan keterampilan tangan, sehingga cenderung bersifat padat karya. Usaha skala besar yang cenderung bersifat padat modal, tentunya akan sulit masuk ke dalam dunia usaha ini. Di sisi lain, hal ini memberikan gambaran pentingnya UMKM dalam penyerapan tenaga kerja, utamanya pada saat krisis ekonomi. Ekonomi kreatif merupakan gelombang ekonomi baru yang mengutamakan intelektual sebagai kekayaan yang dapat menciptakan uang, kesempatan kerja, pendapatan, dan kesejahteraan. Inti ekonomi kreatif terletak pada industri kreatif yang digerakkan oleh para kreator dan inovator melalui kreativitas dan keinovasian (Suryana,2013).

Mitra kegiatan pengabdian adalah dua UMKM Pengrajin Pigura Kaligrafi yaitu UD Roza Jaya di Kota Demak, Endah Pigura di Kota Kudus, Provinsi Jawa Tengah. Mitra tersebut merupakan pengusaha kecil Pengrajin Pigura Kaligrafi, yang menghasilkan produk kaligrafi beserta piguranya sehingga produk yang dijual merupakan satu kesatuan yang tidak bisa dipisahkan antara kaligrafi dan piguranya. Produk kerajinan Pigura Kaligrafi tersebut berpeluang ekspor dan secara tidak langsung telah dibawa ke luar negeri, karena pigura kaligrafi telah diperjual-belikan di wilayahwilayah kunjungan wisatawan Manca Negara serta agen yang berada di luar pulau Jawa, sehingga mitra diklasifikasikan sebagai Eksportir Tidak Langsung (Indirect Exporter)
UMKM yang berorientasi ekspor, menurut (Tambunan, 2003 dalam Jurnal Pengkajian Koperasi dan UMKM No 1 Tahun 1 ) diklasifikasikan menjadi dua, yakni Produsen Eksportir (Direct Exporter) dan Eksportir Tidak Langsung (Indirect Exporter). UMKM Produsen Ekspor adalah UMKM yang menghasilkan produk ekspor dan menjualnya secara langsung kepada pembeli dari luar negeri (buyer) atau importir. Sementara itu, UMKM Eksportir Tidak Langsung adalah UMKM yang menghasilkan produk ekspor, yang melakukan kegiatan ekspor secara tidak secara langsung dengan buyer/importir, tetapi melalui agen perdagangan ekspor atau eksportir dalam negeri. Apabila ditilik dari nilai pangsa ekspor, pangsa nilai ekspor UMKM Eksportir Tidak Langsung sebesar 99,02 persen, sedangkan pangsa ekspor UMKM Produsen Eksportir sebesar 0,98 persen. Namun demikian, tingkat perolehan keuntungan yang diperoleh UMKM Produsen Eksportir lebih besar dibandingkan dengan UMKM Eksportir Tidak Langsung.

Data dari Dinas Perindustian, UMKM dan Koperasi menunjukkan bahwa Pengrajin Pigura Kaligrafi saat ini belum begitu tersentuh keberadaaanya dan memang belum terdata, dimana pengrajin tersebut merupakan salah satu industri kerajinan menghasilkan produksi berbagai macam pigura untuk berbagai seni kaligrafi yang merupakan souvenir khas untuk wisatawan.

\section{METODOLOGI}

Implementasi IImu Pengetahuan dan Teknologi bagi Produk Ekspor ini bertujuan untuk melakukan pemberdayaan pengrajin Pigura Kaligrafi sehingga meningkatkan produksi dan kualitas Pigura Kaligrafi melalui pemanfaatan IImu Pengetahuan dan Teknologi. Implementasi IImu Pengetahuan Teknologi yang dilakukan memberikan beberapa solusi untuk memecahkan permasalahan yang dihadapi mitra dengan metode yang dilaksanakan dalam kegiatan 
adalah Pelatihan dan Bimbingan teknologi ( Bintek ), pendampingan penggunaan sarana dan prasarana produksi yang tepat guna, pada masing-masing aspek ekonomis yang saling terkait dibawah ini.

\subsection{Bahan Baku dan Produk}

Pendampingan dan penguatan dalam produksi berkaitan dengan pemilihan bahan baku pembuatan kaligrafi dan pigura, sehingga pengrajin memiliki kemampuan untuk menghasilkan produk yang berkualitas, diversifikasi atau penganekaragaman produk, serta tidak hanya bertumpu pada produkproduk tradisional. Selain itu diharapkan akan menghasilkan produk yang berdaya saing sebagai upaya meningkatkan kualitas dan inovasi. Agar UMKM Pengrajin pigura kaligrafi mempunyai nilai komersial atas produk yang dihasilkan dan mempunyai nilai tambah, maka perlu diadakan pengembangan produk yang menekankan pada hal-hal sebagai berikut :

a. Pengembangan produk yang berbasis budaya dengan kreasi baru yang beragam.

b. Pengembangan desain produk yang dinamis. Pengembangan desain produk harus dilakukan secara kreatif dan berkesinambungan. Semakin cepat perubahan desain maka cenderung semakin pendek lingkaran hidup produk tersebut ( life cicle of product).

c. Pengembangan standar produk yang sesuai dengan pangsa pasar. Standar produk harus menyesuaiakan dengan kebutuhan pasar. Akan tetapi tidak menutup kemungkinan desain produk bisa diciptakan seniri sehingga desain produk baru untuk mengendalikan pasar/konnsumen ( market driven ).

d. Pengembangan produk yang ramah pengguna ( userfriendly), artinya barang yang dihasilkan memudahkan konsumen untuk memahami, membeli , menggunakan, produk tersebut kapan saja dan dimana saja. e. Pengembangan produk yang fleksibel dan beradaptasi dengan kebutuhan konsumen dan perkembangan teknologi.

f. Pengembangan standar kualitas produk. Perusahaan harus berusaha untuk menciptakan produk-produk kualitas yang terbaik sejak pertama kali.

\subsection{Proses Produksi dan Fasilitas}

Pendampingan dan penguatan dalam proses produksi berkaitan penggunaan sarana prasarana tepat guna dalam pembuatan kaligrafi dan pigura. Dengan menggunakan peralatan yang berbasis mesin akan menjadikan proses produksi menjadi lebih efektif dan efisien.

\subsection{Manajemen, Finansial, SDM dan Pemasaran}

Pendampingan dan penguatan manajemen produksi maka diharapkan pengrajin dapat menyusun rencana produksi, sehingga produksi dapat terpenuhi sesuai kapasitas, tidak terjadi kelebihan produksi ataupun sebaliknya. Pendampingan dalam administrasi , pembukuan ( akuntansi) dan perpajakan diharapkan dapat meningkatkan pengetahuan dan keterampilan teknis dalam kegiatan yang berkaitan dengan ekspor dan penyusunan laporan keuangan, dengan menggunakan teknologi komputer yaitu software program akuntansi khusus untuk usaha kecil. Metode dalam pemasaran memperluas jaringan pemasaran melalui pemasaran on line, membantu fasilitasi dalam mempromosikan produk Kerajinan Pigura Kaligrafi, melalui jalur diplomasi, temu bisnis, dan pameran, baik pada event bilateral maupun multilateral. Pembuatan ecommerce, web dan blog E-Commerce akan menjadikan Produk Pigura Kaligrafi dikenal luas baik dalam negeri maupum luar negeri, sehingga pangsa pasar akan berkembang. Dengan berbagai bimbingan teknologi, pendampingan, training dan penguatan yang 
diberikan kepada pekerja dan pemilik usaha akan menjadikan kualitas SDM meningkat, sehingga akan mampu menerima materi yang akan diberikan. Membantu Pemetaan demand dan supply pada tempat tujuan ekspor. Hal ini akan sangat membantu Pengrajin Pigura Kaligrafi dalam menentukan konsumen .

Secara komersial, produk industri kecil pada umumnya belum memiliki saluran distribusi yang memadai, bersifat lokal, terbatas, menunggu permintaan, kurangnya sarana transportasi, dan komunikasi serta memproduksi tidak berdasrkan pesanan. Penciptaan nilai distribusi dapat dilakukan dengan metode sebagai berikut :

a. Pengembangan informasi pasar melalui riset dan pemantauan kebutuhan konsumen.

Riset pasar dimaksudkan untuk mengetahui keiginan dan kebutuhan konsumen.

b. Pemantauan kekuatan dan kelemahan pangsa pasar.

Pemantauan ini penting untuk melihat keunggulan dan kelemahan bisnis dalam bersaing supaya tetap eksis di pasar.

c. Pengembangan promosi dan pameran. Pengenalan produk kepada kosumen melalui promosi dan pameran sangat efektif untuk meningkatkan permintaan potensial konsumen.

d. Pengembangan teknik promosi melalui media elektronik secara massal oleh dinas terkait.

\section{HASIL DAN PEMBAHASAN}

Kegiatan pengabdian ini memberikan kesempatan kepada institusi untuk bertindak sebagai lembaga layanan terhadap permasalahan yang dihadapi oleh Pengrajin , dan membangun komunikasi melalui artikel ilmiah, dan pada tahap-tahap selanjutnya dengan menjadikan perguruan tinggi sebagai nara sumber ilmiah untuk membantu memecahkan berbagai masalah yang dihadapi terkait ilmu pengetahuan, teknologi dan aplikasinya. Adapun hasil dari kegiatan ini dijelaskan dalam berbagai aspek ekonomis dibawah ini.

\subsection{Bahan Baku dan Produk}

Penggunaan alternatif bahan pigura kayu yaitu fiber menjadi keunggulan dalamproduk karena motif yang variatif, tahan lama karena tidak dimakan rayap. Selain itu untuk kaligrafi menggunakan bahan substitusi dengan berbagai kelebihan seperti bahan kuningan diganti dengan bahan foil, karena mengurangi resiko karat atau jamur.

Jenis, Spesifikasi Produk Pigura Kaligrafi yang sangat beragam sangatlah perlu adanya inventarisasi dan pengkodean melalui Katalog baik secara manual maupun secara komputerisasi yang nantinya akan dihubungkan dengan TV Wall akan memudahkan buyer untuk melihat jenis dari Produk Pigura Kaligrafi. Gambar 1 dibawah ini merupakan gambar berbagai produk pigura Kaligrafi.

Gambar 1. Produk Pigura Kaligrafi Berkualitas
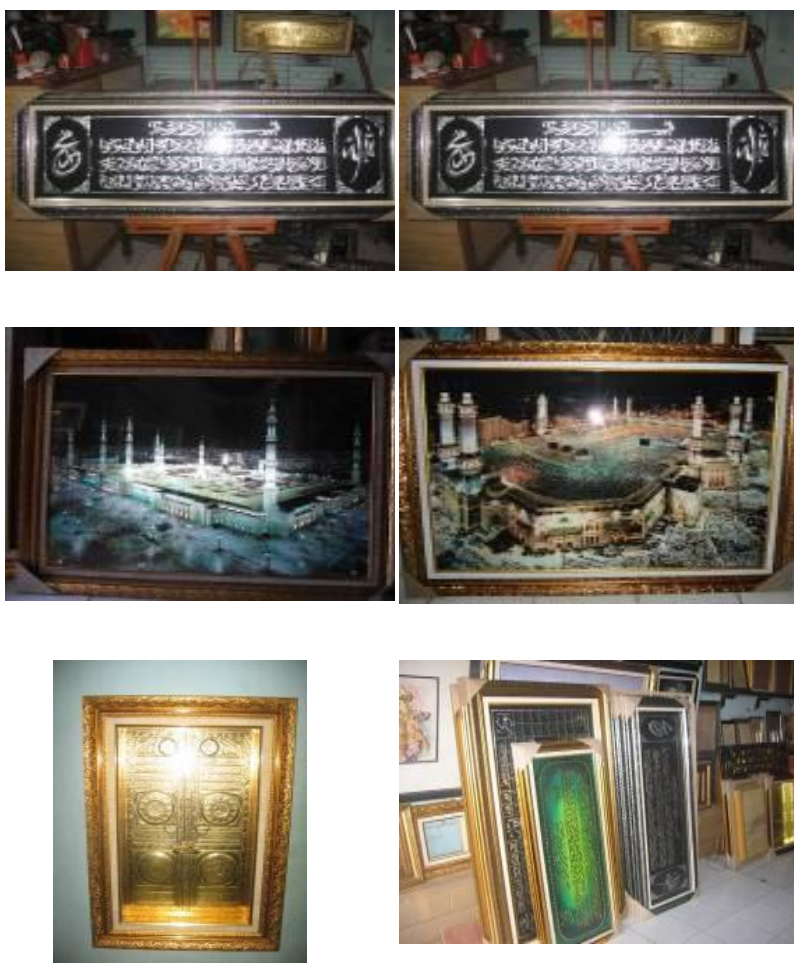

1.5. Proses Produksi dan Fasilitas

Penggunaan sarana dan prasarana berbasis mesin, seperti mesin injek khusus 
sudut pigura, pengunaan gergaji miter khusus untuk memotong sudut pigura, alat pemasang skrup, paku tembak dan lain sebagainya. Dengan fasilitas dan proses efektif dan efisien menjadikan produk yang dihsilkan menjadi berkualitas. Gambar 2 gambar penggunaan sarana prasarana berbasis mesin, tidak lagi menggunakan alat manual.
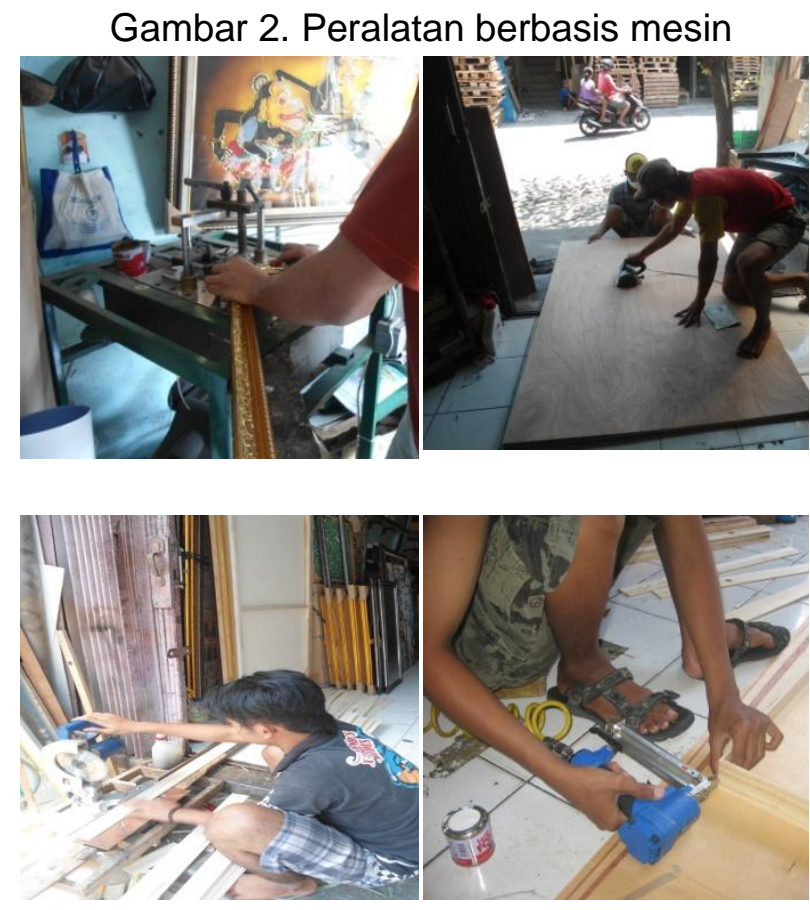

\subsection{Manajemen, Finansial, SDM dan Pemasaran}

Hasil yang lainya adalah adanya sistem manajemen yag lebih tertata, kemudian adanya pengelolaan administrasi keuangan yang lebih baik. Adanya peningkatan dan perluasan pemasaran melalui pemasaran on line serta web UMKM khususnya Pengrajin Pigura Kalirafi.

\section{KESIMPULAN}

Beberapa kesimpulan yang dapat ditarik berdasarkan hasil dan pembahasan adalah sebagai berikut:

(1) Melalui pendampingan dan penguatan dalam proses produksi, menjadikan bahan baku yang digunakan dalam Pigura kaligrafi menjadi berkualitas, serta terciptanya proses produksi yang efektif dan efisien.

(2) Adanya diversifikasi produk serta produk Pigura Kaligrafi yang lebih berkualitas dan memiliki a saing yang lebih tinggi.

(3) Adanya perluasan daerah pemasaran baik lokal, nasional maupun internasional sehingga pendapatan pengrajin pada khususnya meningkat serta peningkatan pendapatn daerah pada umumnya.

\section{UCAPAN TERIMA KASIH}

Tim Pengabdian

Masyarakat mengucapkan terimakasih kepada Direktorat Penelitian Dan Pengabdian Masyarakat Direktorat Jendral Perguruan Tinggi, Kementrian Riset dan Teknologi Pendidikan Tinggi yang telah membiayai kegiatan Pengabdian Iptek Bagi Produk Ekspor tahun 2015 . Ucapan terima kasih juga kami sampaikan kepada UD Roza Jaya Desa Tembiring Demak, Endah Pigura Desa Wergu Wetan Kudus yang telah bersedia menjadi Mitra Pengabdian, Dinas Perindustrian, Koperasi dan UMKM Kabupaten Demak dan Kabupaten Kudus , serta semua civitas akademik Universitas Muria Kudus yang telah memberikan sumbangan baik moril maupun spiritual sehingga kegiatan ini berhasil dilaksanakan.

\section{DAFTAR PUSTAKA}

Biro Pusat Statistik, Kota Kudus Dalam Angka 2014

Biro Pusat Statistik, Kota Demak Dalam Angka 2014

Biro Pusat Statistik, Jawa Tengah Dalam Angka 2011

Chzmin R Muhammad, 2011, Model Manajemen Produksi Tepat Guna pada UKM Sektor Makanan Ringan dengan Kriteria Zero Inventory, Prosiding SNA PI Sains, Teknologi dan Keshatan ISSN 2089,3582 
Jurnal Pengkajian Koperasi dan UKM No 1

Tahun 1-2006, Hambatan Usaha Kecil dan Menengah dalam Kegiatan Ekspor.

Perreault, 2009, Pemasaran Dasar : Pendekatan Manajerial Global Buku 2 , Salemba Empat, Jakarta

Suryana, 2013. Ekonomi Kreatif.Ekonomi Baru:Mengubah Ide dan Menciptakan Peluang, Salemba Empat, Jakarta

Zuliyati Lie Liana, 2012, Desain Produk Multi Media Card bagi Kelompok Pengrajin Pigura, Proceeding Kewirausahaan dan Industri Kreatif, ISBN : 978-979-3986-296, STIE Widya Manggala

Zuliyati, 2015, Peningkatan Kuaitas Produk Pigura Kaligrafi Dalam Rangka Memacu Pertumbuhan Ekspor Melalui Pasar Yang Kompetitif, Prosiding Seminar Nasional Teknologi dan Informatika (SNATIF) ISBN: 978-602-1180-21-1, Universitas Muria Kudus.

http://www.Jateng prov.go.id/

http://www.kudus kab.go.id

http://www.demak kab.go.id/

http://suaramerdeka.com/v1/index.php/read/n ews/2011/04/26/83946/Investasi Industri-Kerajinan-Menurun

http://www.umkmonline.com/detail_berita. 